\title{
СОВМЕСТНЫЕ ПРЕДПРИЯТИЯ В МЕЖДУНАРОДНОМ ЧАСТНОМ ПРАВЕ
}

\begin{abstract}
Аннотация. На сегодняшний день, в юридической науке, встречаются различные термины, описывающие явление в сущности своей тождественное тому, что понимается под "совместным предприятием». Содержание данного термина охватывается чрезвычайно широкий круг объектов: это и юридические лииа, созданные при участии иностранных и национальных учредителей, и договорные формы взаимодействия названных инвесторов, не предполагающие объединения их капитала в рамках правосубъектных организаций. Сам термин «совместное предприятие» используется для обозначения двух юридических понятий: договора, на основании которого действует не обладающее статусом юридического лища товарищество (партнерство) и юридического лица, создаваемого совместными усилиями иностранного и национального инвесторов. При этом важно отметить, что совместное предприятие не является организационно-правовой формой юридического лииа, а лишь может быть создано в одной из организаиионно-правовых форм в том случае, если соинвесторы решат объединить свои капиталь именно в форме юридического лица, правосубъектной организаиии. Таким образом, совместное предприятие выступает в качестве собирательной категории, объединяющей любые виды юридических лии и неправосубъектных организаций, а также договорные формы осуществления совместной деятельности, участниками которых на равных началах являются иностранные и национальные инвесторы. Всем этим вымеописанным проблемам и ряду других и посвящена настоящая статья.
\end{abstract}

Ключевые слова: международное частное право, международное инвестиционное право, совместные предприятия, международные совместные предприятия, коллизионное регулирование, материальное регулирование, иностранный элемент, корпорации, товарищества, партнерства Review: Currently the legal science uses a number of terms for describing the matters identical to those recognized as "joint ventures". The contents of this term include a wide range of objects, including legal entities, which were formed with participation of foreign and national founders, contractual forms of interaction of the above-named investors, not presupposing the joint capitals within legal entities - organizations. The term "joint venture" is used for two legal terms: a contract, based on which a partnership or a fellowship may act, while not having a status of a legal entity, and the legal entity which is formed with the joint efforts of a foreign and a national investors. It is important to note that a joint venture is not a recognized form of a legal entity, and it may be formed within one of the organizational legal forms, if the co-investors should decide to join their capitals via a new legal entity, having legal capacity. Therefore, a joint venture is a collective category, uniting any types of legal entity and organizations, having no independent legal status, as well as the contractual forms of joint activities, in which foreign and national investors participate on equal terms. The article is concerned with the above-mentioned issues, as well as a number of others.

Keywords: international private law, international investment law, joint venture, international joint ventures, conflict of laws regulation, material regulation, foreign element, corporations, partnerships, fellowships.

а сегодняшний день, в юридической науке, встречаются различные термины, описывающие явление в сущности своей тождественное тому, что понимается под «совместным предприятием». Спектр таких мнений может быть представлен следующими наименованиями: «смешанное предприятие», «смешанное общество», «предприятие с иностранными инвестициями», «предприятие с долевым участием иностранных лиц», «организация с иностранны- 
ми инвестициями», «коммерческая организация с долевым участием иностранных инвестиций», «совместная хозяйственная организация» и др. ${ }^{1}$ В зарубежной практике термином, который в наибольшей степени сходен с вышеперечисленными по содержанию, является термин «јoint venture».

Совместное предприятие характеризуется рядом особенностей: объединением капиталов, принадлежащих лицам, участвующим в нем; совместным финансированием и управлением им в целях достижения определенного экономического результата; совместным несением рисков и убытков, а также совместным участием в доходах и их распределении. Большое значение, при этом, придается тому, что совместное предприятие является также и объединением субъектов права, физических и юридических лиц, направленным на сотрудничество в некотором коммерческом мероприятии в течение длительного времени. Например, в прецедентном праве под совместным предприятием понимается «объединение лиц, которые в соответствии с контрактом согласились осуществлять совместную деятельность в целях извлечения прибыли путем объединения соответствующих ресурсов» ${ }^{2}$.

Некоторые специалисты также делают акцент на срочности, целевом характере совместного предприятия, понимая его как «соглашение о совместной деятельности между двумя и более субъектами предпринимательской деятельности в целях достижения конкретной цели или участия в проекте, который может быть успешно реализован в результате объединения ресурсов или технологии» ${ }^{3}$. Кроме того, в законодательстве ряда иностранных государств есть нормативно закрепленные дефиниции понятия «совместное предприятие» (joint venture). Например, согласно Инвестиционному акту Канады от 20 июня 1985 г. $^{4}$ это «ассоциация двух и более физических

\footnotetext{
1 Лисий В.Н. Совместные предприятия в международном частном праве // Законодательство. 2008. №1. С. 67-73.

${ }^{2}$ Battram S.P. Joint Venturing and Investment: Canada's Perspective as a Host Country // International Joint Ventures: A Practical Approach to Working with Foreign Investors in the United States and Abroad. A Case Study with Sample Doc-uments / Ed. by D. N. Goldsweig and R. H. Cummings. Chicago, 1990. P. 388.

${ }^{3}$ Sornarajah $M$. The International Law on Foreign Investment. Cambridge, 1994. Р. 114.

${ }^{4}$ Он заменил собой принятый в 1973 г. закон аналогичного содержания, называемый Законом «о рассмотрении ино-
}

или юридических лиц, в которой отношения между ними не создают в соответствии с правом Канады корпорации, партнерства или траста и в которой в случае осуществления инвестиций, регулируемых данным актом, все нераспределенные имущественные права в отношении канадского бизнеса или права на голосование в организации, составляющие предмет инвестиций, принадлежат или будут принадлежать всем физическим или юридическим лицам - участникам ассоциации».

Следует отметить, что, само понятие «joint venture» происходит из права Шотландии, где под ним понимались объединения ad hoc, образованные несколькими лицами для осуществления определенных разовых проектов. При этом такие объединения противопоставлялись партнерствам, за которыми признавался статус объединений более устойчивых и направленных на продолжительное сотрудничество. В настоящее время данный термин применяется правом таких стран, как США, Англия, Дания. В США, например, «joint venture» представляет собой образование, сходное с «partnership», товариществом, однако всё же не отвечающее всем его признакам, ещё не обладает характеристиками, наличие которых позволяло бы говорить об учреждении полноценного партнерства ${ }^{5}$. С течением времени данное понятие заимствовалось законодателями других стран и приобретало более обширное применение на практике, в частности, при характеристике международных форм взаимодействия предпринимателей. В последнем случае образовался отдельный термин «international joint venture», который приобрел свои собственные специфические черты, как обобщающий для указанных форм

странных инвестиций». Кроме преамбулы, в которой даются определения используемым в Законе понятиям, Закон содержит девять разделов: 1) орган контроля и полномочия (Organization and Mandate); 2) исключения из сферы действия закона (Exemrtion); 3) уведомление (Notification) инвестора; 4) рассмотрение инвестиций (Review); 5) общие нормы о предпринимательской деятельности (Rules and Presumption); 6) подзаконные акты, регулирующие иностранные инвестиции (General Regulation); 7) меры принуждения, правонарушения, штрафы (Remedies, Offences and Penalties); 8) отчет органа контроля (Report); 9) переходные и дополнительные положения, введение закона в действие (Transitional, Consequentional Amendments and Commencement).

${ }^{5}$ Dotevall $R$. Choice of Law rules for International Cooperative agreements. Stockholm Institute for Scandinavian Law, 2009. P. 2. 
международных коммерческих объединений, и уже не имел характера организационно-правовой формы внутригосударственного объединения физических и юридических лиц. Именно в этом значении понятие «joint venture» и применяется в настоящее время применительно к вопросам осуществления зарубежных инвестиций.

Из приведенных нормативных и доктринальных определений совместного предприятия можно увидеть, что содержанием данного термина охватывается чрезвычайно широкий круг объектов: это и юридические лица, созданные при участии иностранных и национальных учредителей, и договорные формы взаимодействия названных инвесторов, не предполагающие объединения их капитала в рамках правосубъектных организаций. Термин «совместное предприятие» используется для обозначения двух юридических понятий: договора, на основании которого действует не обладающее статусом юридического лица товарищество (партнерство) и юридического лица, создаваемого совместными усилиями иностранного и национального инвесторов. При этом важно отметить, что совместное предприятие не является организационно-правовой формой юридического лица, а лишь может быть создано в одной из организационно-правовых форм в случае, если соинвесторы решат объединить свои капиталы именно в форме юридического лица, правосубъектной организации. Таким образом, совместное предприятие выступает в качестве собирательной категории, объединяющей любые виды юридических лиц и неправосубъектных организаций, а также договорные формы осуществления совместной деятельности, участниками которых на равных началах являются иностранные и национальные инвесторы.

Многогранность рассматриваемого явления влечет за собой возможность урегулирования отношений между инвесторами по поводу осуществления совместной деятельности в рамках одной из форм совместного предприятия нормами как корпоративного, так и договорного права. Проблема выбора права в данном случае дополнительно осложняется наличием в указанных отношениях иностранного элемента, которая заключается в потенциальной возможности отказа совместному предприятию в правосубъектности судом. Это позволяет говорить о некой двойственности в регулировании вопросов создания, деятельности и прекращения совместных предприятий, а также отношений между их участниками - фактически, регулирования совместной деятельности хозяйствующих субъектов, принадлежащих к разным правопорядкам, одновременно нормами корпоративного права и права договоров.

Таким образом, «международное совместное предприятие» (international joint venture), является обобщающим понятием ко всем способам осуществления предпринимательской деятельности на территории иностранного по отношению к осуществляющему её лицу государства, связанной с привлечением к участию в такой деятельности хозяйствующих субъектов, принадлежащих как к правопорядку государства места осуществления такой деятельности, так и к отличным от него.

На сегодняшний день отношения по поводу совместных предприятий регулируются только на национальном уровне, что, как указывают иностранные специалисты, ${ }^{6}$ является основной проблемой таких организаций, так как каждая из национальных правовых систем по-разному понимает данную форму объединения. При этом совместное предприятие, рассматриваемое в рамках настоящей статьи как коммерческое объединение хозяйствующих субъектов, принадлежащих к правопорядкам разных государств, существующее в форме правосубъектной организации либо в рамках договора о совместной деятельности, очевидно, может быть связано с правовыми системами нескольких стран. Соответственно, иностранный элемент в таких отношениях проявляется особо отчетливо. Вследствие этого неизбежно возникновение пространственных правовых коллизий между нормами права различных государств и для урегулирования как споров относительно совместных предприятий, так и самих отношений, связанных с ними, необходимо применение коллизионных норм.

При этом едва ли не единственным примером попытки материально-правового регулирования на международном уровне непосредственно совместных предприятий могут являться разрабо-

\footnotetext{
${ }^{6}$ Marcinkevičius L. Prospects for the Regulation of International Joint Ventures. Mykolas Romeris university. Faculty of law. Department of International Law. 2009. P. 2.
} 
танные и принятые Международным торговым центром ЮНКТАД/ВТО (далее - МТЦ) в 2004 и 2005 гг. модельные соглашения об учреждении инкорпорированных совместных предприятий, а также совместных предприятий на контрактной основе ${ }^{7}$. В основном же материальное регулирование совместных предприятий осуществляется средствами общих нормативных актов национальных законодательств. В первую очередь, это корпоративное право и нормы гражданского законодательства, касающиеся договоров простого товарищества. Специальное нормативное регулирование вопросов совместных предприятий, таким образом, является на настоящий момент большой редкостью.

Говоря о коллизионном регулировании совместных предприятий, необходимо, в первую очередь, указать, что для его целей весь объем соответствующих объединений делят на две следующие группы:

- отношения, связанные с совместными предприятиями, образованными на основе юридических лиц;

- отношения, связанные с совместными предприятиями, образованными на контрактной основе.

На примере вышеупомянутых модельных соглашений МТЦ можно видеть, что именно по такому принципу совместные предприятия группируются в международной практике ${ }^{8}$. Коллизионный вопрос признания правосубъектности совместного предприятия возникает в том случае, если отсутствует ясность в определении государственной принадлежности юридического лица - совместного предприятия. И здесь нужно рассмотреть ключевую проблему юридических лиц, относительно которых возможно признание их принадлежности одновременно нескольким государствам - проблему отказа юридическому лицу в правосубъектности. Данная проблема происходит из разницы подходов национальных доктрин государств. Его следствием является различный подход законодателей к определению

\footnotetext{
${ }^{7}$ ITC Incorporated Joint Venture Model Agreements, 2005. International Trade Centre Unctad/WTO. Geneva: ITC (Trade Law Series). United Nations, 2005. А также: ITC Contractual Joint Venture Model Agreements, 2004.

${ }^{8}$ Marcinkevičius L. Op. cit. P. 2.
}

самой природы юридического лица, которая выражается, в частности, в применении в разных государствах отличных коллизионных привязок для определения личного закона юридического лица. В первую очередь это касается конфликта критериев инкорпорации и эффективной оседлости.

В государствах, коллизионное право которых применяет критерий инкорпорации, отказ совместному предприятию в правосубъектности возможен почти лишь только в том случае, если оно было учреждено с нарушениями законодательства государства своего учреждения. В то же время критерий эффективной оседлости, как можно видеть на примере законодательства и судебной практики ФРГ, во многих случаях ведет к отказу юридическому лицу в правосубъектности. Так, например, если администрация юридического лица, учрежденного по иностранному праву, размещена в Германии, её суд, руководствуясь критерием оседлости, и, тем самым применяя собственное право, устанавливает для этого юридического лица, возможно, невыполнимые требования. Возможна также ситуация, при которой немецким судом может быть отказано в правосубъектности юридическому лицу, учрежденному в соответствии с правом Германии, однако осуществляющему свою деятельность на территории другого государства9. Наиболее наглядно проблема соотношения критерия оседлости и критерия инкорпорации проявляется на территории Европейского Союза (далее - EC, Евросоюз), где при декларируемых главами (раздел IV) Договора о функционировании Европейского Союза ${ }^{10}$ свободах перемещения лиц

\footnotetext{
${ }^{9}$ Kадымева O.В. Национальность юридических лиц в международном частном праве: Дис. ... канд. юрид. наук. М., 2002. С. 115 .

10 «Новый» Союз функционирует на основании двух учредительных документов, имеющих одинаковую (высшую) юридическую силу в его правовой системе. Во-первых, краткий основополагающий договор, содержащий общие принципы устройства Союза: Договор о Европейском Союзе 1992 года. Во-вторых, наиболее важный по значению и самый крупный по объему учредительный документ Союза: Договор о функционировании Европейского Союза 1957 года. Оба договора действуют в редакции Лиссабонского договора от 13 декабря 2007 года, вступившего в силу 01 декабря 2009 года, изменяющего Договор о Европейском Союзе 1992 года и Договор об учреждении Европейского Сообщества 1957 года (далее - Договор о ЕС).
} 
капиталов, товаров и услуг, а также свободе учреждения, разница в коллизионном регулировании юридических лиц зачастую не позволяет коммерческим организациям осуществлять деятельность вне территории государства своего учреждения.

Данная проблема связана с вопросом перемещения административного центра юридического лица (а именно его местонахождение в соответствии с критерием эффективной оседлости определяет право, являющееся его личным законом) с территории государства своего учреждения на территорию другой страны. Она вызвана тем, что большинство западноевропейских государств, входящих в состав ЕС, придерживаются критерия эффективной оседлости, который и устанавливает преграды на пути такого перенесения. Перенос за границу компаниями местонахождения своих штаб - квартир без потери первоначальной правосубъектности в большинстве государств - членов ЕС невозможен или сопряжен со значительными трудностями. Поэтому интернационализация постоянной хозяйственной деятельности в странах сообщества осуществляется путем создания филиалов, дочерних компаний, различных форм участия в капитале местных фирм, слияний с ними и т.д.

На сегодняшний день, критерий эффективной оседлости применяется такими странами Евросоюза, как Австрия, Германия, Греция, Латвия, Литва, Польша, Португалия, Франция, Бельгия, Лихтенштейн, Люксембург, Швейцария и Италия. Критерий инкорпорации, при этом, используется в Великобритании, Дании, Нидерландах и Ирландии. Если законодательство Люксембурга, Бельгии, Лихтенштейна и Швейцарии еще предусматривает возможность сохранения правосубъектности иностранной компании, которая перенесла свой основной административный орган на территорию этих государств, то, например, как уже указывалось, позиция Германии в этом вопросе является наиболее жесткой, влекущей в подавляющем большинстве случаев ликвидацию такого юридического лица. В частности, ст. 161 Федерального закона Швейцарии «О международном частном праве» от 18 декабря 1987 г. ${ }^{11}$ предусматривает,

${ }^{11}$ Switzerland's Federal Code on Private International Law (CPIL). Swiss CPIL, Umbricht Attorneys, Zurich (Switzerland) 2007. All что «иностранное товарищество может принять принадлежность швейцарскому праву без ликвидации и повторного учреждения, если это допускается иностранным правом, которому подчиняется товарищество. Такое товарищество должно выполнить требования иностранного права и иметь возможность адаптироваться к одной из организационно - правовых форм, предусмотренных швейцарским правом» ${ }^{12}$.

Наиболее развернуто вопрос признания иностранных юридических лиц решен в законодательстве княжества Лихтенштейн (в ст. 233 Закона «Об изменении регулирования о лицах и обществах» $1996 \Gamma^{13}{ }^{13}$ под заголовком «Перенесение объединения из-за границы внутрь страны»):

1. Иностранное объединение может с разрешения суда земли посредством внесения в публичный реестр и назначения представителя, причем и то и другое является необходимым, без прекращения за границей и без нового учреждения внутри страны или без перенесения своих деловой деятельности или (органа) управления подчиниться местному (лихтенштейнскому) праву и тем самым перенести свое местонахождение внутрь страны (Лихтенштейна).

2. Это разрешение может быть дано, только если объединение докажет, что оно приведено в соответствие с местным (лихтенштейнским) правом и что иностранное право допускает перенесение объединения.

3. Объединение должно до внесения (в реестр) доказать, что объявленный в учредительных документах как полностью оплаченный основной капитал на момент перенесения объединения является покрытым.

4. Объединение, которое согласно местному праву не подлежит внесению в реестр, подчиняется местному праву, как только является отчетливо различимой воля подчиниться местному праву, существует достаточная

footnotes are omitted. They are available at: www.admin.ch/ch/d/ sr/2/291.de.pdf.

${ }^{12}$ Асосков А.В. Правовые формы участия юридических лиц в международном коммерческом обороте. М.: Статут, 2003. C. 30 .

13 Закон об изменении регулирования о лицах и обществах 1996 г. // http://pravo.hse.ru/intprilaw/doc/042802 
связь с Лихтенштейном и последовало приведение (объединения) в соответствие с местным правом ${ }^{14}$.

Таким образом, можно видеть, что некоторые европейские страны в целях разрешения рассматриваемой проблемы прибегают к установлению дополнительных административных процедур допуска иностранных юридических лиц на свою территорию, которая, как видно, заключается, в первую очередь, в установлении соответствия такой организации требованиям законодательства принимающего государства к своим юридическим лицам.

Говоря о проблеме признания юридических лиц на территории Евросоюза, нельзя не упомянуть о роли судебной практики в развитии подходов к её разрешению. В частности, вопрос о соотношении теории оседлости и положений Договора о ЕС не раз оказывался в поле зрения Европейского суда (решения по делу «Daily Mail»» ${ }^{15}$, по делу «Centros» ${ }^{16}$, по делу «Uberseering» $\left.{ }^{17}\right)$. Если в решении по делу «Daily Mail» суд расценил проблему перенесения компаниями своего места нахождения из одного государства - члена ЕС в другое как неурегулированную ст. 43 Договора о ЕС, «учитывая состояние права компаний на тот период времени», то решение по делу «Centros» интерпретируется как «начало конца» теории оседлости, а решение по делу «Uberseering» явилось компромиссом между двумя этими решениями ${ }^{18}$.

В рамках Евросоюза также принимались попытки разрешить проблему соотношения коллизионных критериев инкорпорации и эффективной оседлости и на общеевропейском уровне. Так, 29 февраля 1968 г. была подписана Брюссельская конвенция о взаимном признании компаний. Основной принцип, использованный её разработчиками, - принцип инкорпорации компаний. Предполагалось ввести важное правило о том, что в случае если компания инкорпорирована в од-

\footnotetext{
${ }^{14}$ Асосков А.В. Указ. Соч. С. 32.

${ }^{15}$ См.: дело C-81/87 «Daily Mail» [1988].

${ }^{16}$ См.: дело C-212/97 «Centros» [1999].

${ }^{17}$ См.: дело С-208/00 «Uberseering» [2002].

${ }^{18}$ Дубовиџкая Е.A. Европейское корпоративное право: Свобода перемещения компаний в Европейском сообществе. М., 2004. C. 23 .
}

ной из стран - участниц, а её административный центр находится в другой стране - участнице, то остальные страны Евросоюза обязаны признавать такую компанию. При этом страна местонахождения административного центра получала право применять к таким компаниям императивные нормы собственных законов, которым подчиняются аналогичные типы местных компаний, включая нормы, регулирующие их создание и прекращение. В то же время нахождение административного центра компании вне территории стран ЕС предоставляло государствам возможность отказывать таким компаниям в признании на том основании, что их деятельность не имеет «серьезной связи» с экономикой одной из стран «общего рынка». Однако Брюссельская конвенция о взаимном признании компаний 1968 г. так и не вступила в силу вследствие отказа Нидерландов от ее ратификации ${ }^{19}$. Стоит отметить, что данная конвенция была ратифицированная ФРГ, иногда используется в ее судебной практике ${ }^{20}$. Похожая судьба постигла и Гаагскую конвенцию «О признании правосубъектности иностранных обществ, ассоциаций и учреждений» ${ }^{21}$, подписанную 1 июня 1956 г., но так и не вступившую в силу из-за недостаточного числа ратификаций.

Материально-правовое регулирование юридических лиц в ЕС осуществляется на основании Директив Европейского Парламента и Совета, которые устанавливают унифицированные требования к национальным корпоративным законодательствам государств-членов ЕС, на основании которых, в свою очередь, осуществляется регулирование юридических лиц. К таковым относятся:

- Первая директива о публикации (Directive 2009/101/EC of the European Parliament and of the Council of 16 September 2009 on coordination of safeguards which, for the protection of the interests of members and third parties, are required

\footnotetext{
${ }^{19}$ Более подробно см.: Юмашев Ю.М. Правовое регулирование прямых иностранных капиталовложений в ЕЭС. М., 1988. C. $84-87$.

20 Звеков В.П. Коллизии законов в международном частном праве М.: Издательство Волтерс Клувер, 2007. С. 249.

${ }^{21}$ Конвенция о признании правосубъектностииностранных обществ, ассоциаций и учреждений от 1 июня 1956 г. // СПС «Гарант».
} 
by Member States of companies within the meaning of the second paragraph of Article 48 of the Treaty, with a view to making such safeguards equivalent ${ }^{22}$ );

- Вторая директива о капитале (Second Council Directive 77/91/EEC of 13 December 1976 on coordination of safeguards which, for the protection of the interests of members and others, are required by Member States of companies within the meaning of the second paragraph of Article 58 of the Treaty, in respect of the formation of public limited liability companies and the maintenance and alteration of their capital, with a view to making such safeguards equivalent ${ }^{23}$ );

- Третья директива о слиянии (Third Council Directive 78/855/EEC of 9 October 1978 based on Article $54(3)(\mathrm{g})$ of the Treaty concerning mergers of public limited liability companies $\left.{ }^{24}\right)$;

- Шестая директива о разделении (Sixth Council Directive 82/891/EEC of 17 December 1982 based on Article 54 (3) (g) of the Treaty, concerning the division of public limited liability companies ${ }^{25}$ );

- Десятая директива о трансграничном слиянии (Directive 2005/56/EC of the European Parliament and of the Council of 26 October 2005 on cross-border mergers of limited liability companies $\left.{ }^{26}\right)$;

- Одиннадцатая директива о филиалах (Eleventh Council Directive 89/666/EEC of 21 December 1989 concerning disclosure requirements in respect of branches opened in a Member State by certain types of company governed by the law of another State $^{27}$;

- Двенадцатая директива об обществах одного лица (Directive 2009/102/EC of the European Parliament and of the Council of 16 September 2009 in the area of company law on single-member private limited liability companies $^{28}$ );
- Тринадцатая директива о поглощениях (Directive 2004/25/EC of the European Parliament and of the Council of 21 april 2004 on takeover bids ${ }^{29}$ );

- Директива о правах акционеров (Directive 2007/36/EC of the European Parliament and of the Council of 11 July 2007 on the exercise of certain rights of shareholders in listed companies ${ }^{30}$ ).

В заключение описания регулирования совместных предприятий - юридических лиц на территории ЕС необходимо указать на возможность для инвесторов образовать совместное предприятие в форме «Европейской компании» (Societas Europaea, SE), основное регулирование которых закреплено Регламентом Совета ЕС № 2157/2001 от 8 октября 2001 г. ${ }^{31}$ (далее - Регламент Совета ЕС № 2157/2001), либо же в форме «Европейского объединения с общей экономической целью», урегулированного Регламентом Совета ЕС № 2137/85 от 25 июля 1985 г. ${ }^{32}$ (далее - Регламент Совета ЕС № 2137/85). Помимо данных Регламентов, регулирование организаций данных организационноправовых форм осуществляется субсидиарным применением, в первую очередь - их уставов и, во вторую, - законодательством страны места нахождения их управляющих органов.

Европейское объединение характеризуется тем, что такие организации создаются исключительно для оказания организационной, управленческой помощи в осуществлении деятельности своих участников, но не вправе заниматься какойлибо хозяйственной деятельностью, отличной от предмета деятельности участников Европейского объединения. Европейское объединение не имеет собственного уставного капитала, его участники несут неограниченную солидарную ответственность по долгам, и, более того, в соответствии с национальным законодательством Европейское объединение может не считаться юридическим лицом (например, в Германии и Италии) $)^{33}$.

\footnotetext{
${ }^{29}$ OJ L 142. 30.4.2004. P. 12-23.

${ }^{30}$ OJ L 184. 14.7.2007. P. 17-24.

${ }^{31}$ Council Regulation (EC) № 2157/2011 of October 2001 on the Statute for a European Company (SE) // OJ L 294. 10.11.2001. P. 0001-0021.

32 Регламентом Совета ЕС № 2137/85 от 25 июля 1985 г. «О Европейском объединении с общей экономической целью» // СПС «Консультант Плюс».

${ }^{33}$ Асосков А.В. Указ. Соч. С. 155.
} 
Европейская компания представляет собой аналог национальных акционерных обществ, обладая, при этом, как и Европейское объединение, наднациональным характером. Однако Регламент Совета ЕС № 2157/2001 содержит более подробное материально-правовое и коллизионное регулирование, нежели Регламент Совета ЕС № 2137/85, что влечет, соответственно, меньшую её зависимость от национальных законодательств стран ЕС, большую выраженность её наднационального характера.

Важным требованием к составу учредителей Европейской компании, которое имеет значение применительно к совместным предприятиям, является необходимость наличия в их составе как минимум двух лиц, принадлежащих правопорядку стран - участниц EC, либо на протяжении не менее двух предшествующих учреждению лет имевших дочернюю компанию или филиал на территории страны - участницы ЕС. Ст. 2 Регламента Совета ЕС № 2157/2001, содержащая данное требование, устанавливает также 4 возможных способа создания Европейской компании: учреждение путем слияния, создание головной холдинговой компании по отношению к учредителям - юридическим лицам, учреждение дочерней компании, а также преобразование существующего акционерного общества в Европейскую компанию. Третий из способов является наиболее широким по субъектному составу, что делает его наиболее подходящим для иностранных инвесторов.

Зарубежные специалисты выделяют следующие важные черты Европейской компании, делающие её предпочтительной формой для организации совместных предприятий:

- свобода от организационно-правовых форм, предусмотренных национальными законодательствами, возможность учредить совместное предприятие на территории любого из государств ЕС именно в форме Европейской компании и руководствоваться при этом единым Регламентом;

- возможность использовать единую административную структуру для компании, осуществляющей свою деятельность на территории всей объединенной Европы, без необходимости создавать сеть дочерних организаций, а также сталкиваться с проблемой отказа в правосубъектности;
- $\quad$ отсутствие преград к перемещению Европейской компании из одного государства ЕС в другое, что позволяет следовать трендам международного рынка ${ }^{34}$.

Совместное предприятие - юридическое лицо, как объединение учредителей, принадлежащих к различным правовым системам, само по себе является также и способом преодоления конфликта критериев оседлости и инкорпорации. Коммерческая организация, осуществляющая постоянную деятельность на территории одного государства, может путем вступления в состав участников организации, учрежденной на территории другого, таким образом, пусть и опосредованно, но выйти на рынок этой страны. Не обращаться к прямому перенесению части своих деловых операций на её территорию, принимая на себя риск отказа в правосубъектности при возникновении спора, но, продолжая ведение своей основной деятельности, организовать дело в другой стране, разделив, при этом, риски с местным инвестором. Участие последнего, при этом, будет также гарантировать скорейшую адаптацию к условиям нового для иностранного инвестора рынка.

Наличие определенной доли национального капитала в таком совместном предприятии, кроме того, будет существенно влиять на признание такой организации теми государствами, правовая система которых при определении личного закона юридического лица обращается к критерию реального контроля (критерию государственной принадлежности участников юридического лица). Именно применительно к совместным предприятиям критерий контроля имеет особенное значение, поскольку их учредители могут, корректируя соотношение своих долей в предприятии, таким образом, значительно влиять на его правовой статус.

Итак, материально-правовое регулирование совместных предприятий, за которыми признается статус юридического лица, осуществляется в соответствии с их личным законом. Наличие в уставном капитале коммерческой организации долей, принадлежащих физическим и юридическим лицам, связанным с различными правопорядками, в большинстве случаев не влияет на государственную

${ }^{34}$ Hewitt I. Joint Ventures. 3-rd ed. Sweet \& Maxwell. London. 2005. P. 108. 
принадлежность этого совместного предприятия, $\mathrm{a}$, как следствие, и на выбор права, составляющего статут этого юридического лица. Совместное предприятие, организация с иностранными инвестициями являются юридическими лицами государства, с правопорядком которого они связаны, и в этом смысле их регулирование не отличается от регулирования национальных юридических лиц. Они не являются иностранными юридическими лицами по отношению к правопорядку, в котором действуют, и, следовательно, коллизионный вопрос их правосубъектности может возникнуть только при условии их участия во внешнеэкономических сделках.

Совместные предприятия - товарищества (partnerships), в целом регулируются по тому же принципу, что и совместные предприятия - хозяйственные общества, компании. С той лишь разницей, что они находятся ближе к грани, разделяющей объединения лиц, обладающие самостоятельностью, от таковых, не способных выступать в гражданском обороте в качестве участников отношений. Такие объединения в соответствии с законодательствами одних государств относятся к юридическим лицам, в то время как правовые системы других стран не наделяют их таким статусом, считая их сотрудничеством в рамках договора, не имеющим юридических последствий для третьих лиц.

Так, в континентальном праве выделяется два вида товариществ: полное товарищество и коммандитное товарищество. Полное товарищество (в Германии - die offene Handelsgesellschaft, во Франции - societe en nom collectif) - это договорное объединение лиц для ведения совместной предпринимательской деятельности под единым наименованием. При этом в одних странах полное товарищество признается юридическим лицом (например, во Франции и Италии), в других не признается (например, в Германии и Швейцарии). В Англии и США деятельность полных товариществ (general partnership) регулируется английским Законом о партнерстве 1890 г. ${ }^{35}$ и американским Единообразным законом о партнерстве 1914 г. ${ }^{36}$

\footnotetext{
${ }^{35}$ Partnership Act 1890 // http://www.legislation.gov.uk/ukpga/ Vict/53-54/39

${ }^{36}$ Uniform Partnership Act 1914 // http://lawschool.mikeshecket. com/ba/uniformpartnershipact1914.htm
}

Здесь полные товарищества (партнерства) не признаются юридическими лицами.

Коммандитное товарищество (В Германии - Kommanditgesellschaft, во Франции - des societes a responsabilite limitee) также является договорным объединением лиц для совместной предпринимательской деятельности и признается юридическим лицом. Участниками коммандитного товарищества являются лица, которые отвечают всем своим имуществом по обязательствам товарищества, и лица, которые несут риск убытков в пределах внесенного вклада (коммандитисты). Коммандитисты не имеют права выступать в отношениях с третьими лицами в качестве представителей товарищества, не имеют права на ведение дел товарищества. В Англии и США аналогом коммандитного товарищества является партнерство с ограниченной ответственностью (Limited Partnership), статус которого определен Единообразным законом США о партнерстве с ограниченной ответственностью 1916 г. и Законом Англии о партнерстве с ограниченной ответственностью 1907 г. ${ }^{37}$.

В соответствии же со ст. 48 Гражданского кодекса Российской Федерации ${ }^{38}$ (далее - ГК РФ), хозяйственные общества в России (в числе которых полное и коммандитное товарищество) относятся к юридическим лицам. В российском гражданском праве выделяется также и договор простого товарищества (также именуемый договором о совместной деятельности), в силу которого двое или несколько лиц обязуются соединить свои вклады и совместно действовать без образования юридического лица для извлечения прибыли или достижения иной не противоречащей закону цели (ч. 1 ст. 1041 ГК РФ). При этом, если договор заключается с целью извлечения прибыли, и, в силу этого, является предпринимательским, то, в силу ч. 2 ст. 1041, может заключаться только индивидуальными предпринимателями и коммерческими организациями.

\footnotetext{
37 Более подробно об этом см.: Попондопуло В.Ф. Формы осуществления предпринимательской деятельности на территории России // Предпринимательское право. 2005. № 4. C. $12-24$.

${ }^{38}$ СЗ РФ. 1994. № 32. Ст. 3301.
} 
Отечественное коллизионное регулирование договора простого товарищества предполагает принцип наиболее тесной связи, избирая в качестве права, применимого к данной разновидности договоров, право страны, где в основном осуществляется деятельность объединения, образованного им (пп. 2 п. 4. ст. 1211 ГК РФ). При этом нельзя забывать, что по общему правилу в отношении договоров простого товарищества действует lex voluntatis, то есть право, избранное сторонами договора на основании принципа автономии их воли. Правовой статус хозяйственных товариществ и аналогичных им иностранных коммерческих объединений может определяться на основании коллизионных норм, содержащихся в ст. 1202 и 1203 ГК РФ, соответственно, по критерию инкорпорации для товариществ, признаваемых юридическими лицами, и товариществ, таковыми по иностранному законодательству не являющихся.

Раздел VI ГК РФ во многом был основан на положениях Римской конвенции 1980 г. о праве применимом к договорным обязательствам (далее - Римская конвенция 1980 г.) ${ }^{39}$, которая в настоящий момент заменена на территории ЕС Регламентом Европейского Парламента и Совета № 593/2008 о праве, применимом к договорным обязательствам (далее - Регламент Рим I) ${ }^{40}$. Последний хоть и основывается на положения Римской конвенции 1980 г., однако никоим образом не является его дословным воспроизведением для целей унификации коллизионного права на

\footnotetext{
${ }^{39}$ Римская конвенция 1980 г. вступила в силу 1 апреля 1991 г., однако ряд европейских стран имплементировали ее положения в свое национальное законодательство намного раньше. В частности, во Франции Законом от 21 июня 1982 г. № 82-523, в Италии - Законом от 18 декабря 1984 г. № 975, в Федеративной Республике Германия-Законом от 25 июля 1986 г. См.: Plender R., Wilderspin $M$. The European Contracts Convention: The Rome Convention on the Choice of Law for Contracts. 2nd ed. London, 2001. Неофициальный русский перевод Римской конвенции 1980 г. см.: Вилкова Н.Г. Договорное право в международном обороте. М., 2004. С. 454-466.

${ }^{40}$ Regulation (EC) № 593/2008 of the European Parliament and of the Council of 17 June 2008 on the law applicable to contractual obligations (Rome I). Данный Регламент применяется к контрактам, которые были заключены после 17 декабря 2009 г. Текст документа доступен по адресу:

http://europa.eu.int/eur-lex/lex/LexUriServ/site/en/com/2005/ com2005 0650en01.pdf.
}

территории всего Евросоюза с учетом государств, вошедших в него с 1980 г. ${ }^{41}$. Как и Римская конвенция 1980 г., Регламент Рим I, несмотря на то, что он действует в первую очередь на территории стран ЕС, позволяет применять право третьих по отношению к ЕС государств (ст. 2). Таким образом, для применения Регламента Рим I нет необходимости в том, чтобы сторона - участник спора была зарегистрирована или находилась на территории государства ЕC, и единственным условием его применения является рассмотрение соответствующего спора в суде государства ЕС.

Как заключил Европейский суд по делу «Daily Mail», компании и объединения являются продуктами национальных правовых систем, а регулирование вопросов, связанных с ними, не имеет должной степени унификации. Следовательно, в решении вопроса о применимости Регламента Рим I к товариществам (partnerships) отправной точкой являются положения национальных законодательств стран, из которых происходят конкретные объединения ${ }^{42}$. Иностранные специалисты указывают, что понятием «внутренняя организация» охватываются такие вопросы, как проведение собраний участников, порядок голосования, вопросы кворума, а также процедура назначения лиц на управляющие должности компании или объединения ${ }^{43}$. Наличие указанных органов, а также необходимость разрешать соответствующие вопросы применительно к объединению конкретной формы, всё это указывает на способность такого объединения выступать самостоятельно в отношениях с третьими лицами, наличии у него правосубъектности. Следовательно, объединения, не наделенные такими признаками, могут регулироваться Регламентом Рим I. Нерегистрируемые товарищества (фактически, по российскому праву, объединения на основании договора простого товарищества) и их эквиваленты, например по праву Германии и Франции, таким образом, вряд ли могут быть признаны товариществами в рамках Регламента Рим I, а, следовательно, соглаше-

\footnotetext{
${ }^{41}$ Vernooij N.W. Rome I. An update on the law applicable to contractual obligations in Europe // The Columbia Journal of European Law Online. P. 2.

${ }^{42}$ Dotevall R. Op. cit. P. 4.

${ }^{43}$ Ibid.
} 
ния об их создании подпадают под его действие, как договоры о совместной деятельности. Также нет сомнения, что к соглашениям о совместной деятельности по праву Великобритании и США, а также Дании (termed joint ventures) таким же образом могут быть применены положения Регламента Рим I.

Таким образом, определяющим фактором в коллизионно-правовом регулировании совместных предприятий является их форма. Создание иностранными инвесторами юридического лица, самостоятельной, правосубъектной организации в форме хозяйственного общества делает конкретное совместное предприятие менее гибким, и в значительной степени привязанным к территории того государства, на территории которого оно учреждено, расположено или действует. Однако, в то же время, это предполагает большую ясность в вопросах выбора применимого права, а, следовательно, и в вопросе признания такого юридического лица, а также обеспечивает большую защищенность учредителей от предпринимательских рисков.

Подводя итог, необходимо отметить, что, как и многие из явлений международного коммерческого оборота, совместное предприятие отличается крайней неоднозначностью. Многообразие юридических доктрин, а, следовательно, и законодательных подходов к пониманию и определению форм и способов объединения лиц в целях осуществления предпринимательской деятельности, заведомо влечет невозможность однозначного толкования определенных понятий на основании анализа национальных правовых систем.

В настоящее время совместное предприятие рассматривается международной практикой в первую очередь в качестве коммерческого объединения предпринимателей, принадлежащих разным правовым системам - как международное совместное предприятие (international joint venture). Причем понятие «совместное предприятие» характеризует в первую очередь цель объединения - объединение принадлежащих различным правопорядкам лиц и их капиталов для определенной совместной коммерческой деятельности, но не его форму. Так, само сов- местное предприятие может принимать форму юридического лица - акционерного общества, общества с ограниченной ответственностью либо полного или коммандитного товарищества. В то же время совместное предприятие может быть создано исключительно на договорной основе - в рамках договора простого товарищества. Таким образом, совместное предприятие не является организационноправовой формой юридического лица, а, напротив, является понятием обобщающим по отношению к юридическим лицам, различным неправосубъектным организациям, а также объединениям на договорной основе.

В зависимости от той формы, в которой создается совместное предприятие, его участники, соответственно, сталкиваются с рядом проблем, присущих каждой из таких форм. Ключевым, однако, является вопрос признания за совместным предприятием гражданской правосубъектности, способности самостоятельно выступать в отношениях с третьими лицами, приобретая для себя права и обязанности. Правосубъектность совместного предприятия - юридического лица определяется по его личному закону, выбор которого, соответственно, происходит на основании коллизионных норм законодательства страны суда, в котором рассматривается спор с участием конкретного объединения.

В отношении же договорных форм совместных предприятий действуют коллизионные нормы, касающиеся обязательственного статута договора. Кроме того, бесспорным является наличие автономии воли сторон соглашения о совместной деятельности - в отличие от корпоративной формы совместного предприятия, договорная форма позволяет его участникам подчинить свои отношения наиболее выгодному для них правопорядку, в то время как совместное предприятие оказывается привязанным к тому или иному государству. Важно указать, что совместные предприятия не имеют наднационального характера - данные объединения целиком привязаны к тому или иному правопорядку либо нескольким из них.

Однако очевидно, что юридические лица, как одна из форм совместных предприятий, слишком сильно связаны с правопорядком госу- 
дарства, на основании норм которого они были учреждены, для того, чтобы вопросы создания совместных предприятий в корпоративной форме регулировались на основании норм lex mercatoria с присущей ей размытостью и неопределенностью. Представляется, что посредством мягкого права, на уровне, например, актов Международной Торговой Палаты, в первую очередь могла бы быть унифицирована сама концепция международных совместных предприятий, с тем, чтобы, посредством широкого применения её на практике, впоследствии имплементировать её и в национальные правовые системы. Именно в этом, в первую очередь, видится путь, по которому может быть достигнут консенсус относительно такого важного в условиях современной мировой торговли явления, как международные совместные предприятия.

\section{Библиография:}

1. Асосков А.В. Правовые формы участия юридических лиц в международном коммерческом обороте. М.: Статут, 2003;

2. Вилкова Н.Г. Договорное право в международном обороте. М., 2004;

3. Дубовицкая Е.А. Европейское корпоративное право: Свобода перемещения компаний в Европейском сообществе. М., 2004;

4. Звеков В.П. Коллизии законов в международном частном праве М.: Издательство Волтерс Клувер, 2007 ;

5. Кадышева О.В. Национальность юридических лиц в международном частном праве: Дис. ... канд. юрид. наук. М., 2002;

6. Лисица В.Н. Совместные предприятия в международном частном праве // Законодательство. 2008. №1;

7. Попондопуло В.Ф. Формы осуществления предпринимательской деятельности на территории России // Предпринимательское право. 2005. № 4;

8. Юмашев Ю.М. Правовое регулирование прямых иностранных капиталовложений в ЕЭС. М., 1988;

9. Battram S.P. Joint Venturing and Investment: Canada's Perspective as a Host Country // International Joint Ventures: A Practical Approach to Working with Foreign Investors in the United States and Abroad. A Case Study with Sample Doc-uments / Ed. by D. N. Goldsweig and R. H. Cummings. Chicago, 1990;

10. Dotevall R. Choice of Law rules for International Cooperative agreements. Stockholm Institute for Scandinavian Law, 2009;

11. Hewitt I. Joint Ventures. 3-rd ed. Sweet \& Maxwell. London. 2005;

12. Marcinkevičius L. Prospects for the Regulation of International Joint Ventures. Mykolas Romeris university. Faculty of law. Department of International Law. 2009;

13. Plender R., Wilderspin M. The European Contracts Convention: The Rome Convention on the Choice of Law for Contracts. 2nd ed. London, 2001;

14. Sornarajah M. The International Law on Foreign Investment. Cambridge, 1994;

15. Vernooij N.W. Rome I. An update on the law applicable to contractual obligations in Europe // The Columbia Journal of European Law Online

\section{References (transliteration):}

1. Asoskov A.V. Pravovye formy uchastiya yuridicheskikh lits v mezhdunarodnom kommercheskom oborote. M.: Statut, 2003;

2. Vilkova N.G. Dogovornoe pravo v mezhdunarodnom oborote. M., 2004;

3. Dubovitskaya E.A. Evropeiskoe korporativnoe pravo: Svoboda peremeshcheniya kompanii v Evropeiskom soobshchestve. M., 2004; 
4. Zvekov V.P. Kollizii zakonov v mezhdunarodnom chastnom prave M.: Izdatel'stvo Volters Kluver, 2007;

5. Kadysheva O.V. Natsional'nost' yuridicheskikh lits v mezhdunarodnom chastnom prave: Dis. ... kand. yurid. nauk. M., 2002;

6. Lisitsa V.N. Sovmestnye predpriyatiya v mezhdunarodnom chastnom prave // Zakonodatel'stvo. 2008. №1;

7. Popondopulo V.F. Formy osushchestvleniya predprinimatel'skoi deyatel'nosti na territorii Rossii // Predprinimatel'skoe pravo. 2005. № 4;

8. Yumashev Yu.M. Pravovoe regulirovanie pryamykh inostrannykh kapitalovlozhenii v EES. M., 1988;

9. Battram S.P. Joint Venturing and Investment: Canada's Perspective as a Host Country // International Joint Ventures: A Practical Approach to Working with Foreign Investors in the United States and Abroad. A Case Study with Sample Doc-uments / Ed. by D. N. Goldsweig and R. H. Cummings. Chicago, 1990;

10. Dotevall R. Choice of Law rules for International Cooperative agreements. Stockholm Institute for Scandinavian Law, 2009;

11. Hewitt I. Joint Ventures. 3-rd ed. Sweet \& Maxwell. London. 2005;

12. Marcinkevičius L. Prospects for the Regulation of International Joint Ventures. Mykolas Romeris university. Faculty of law. Department of International Law. 2009;

13. Plender R., Wilderspin M. The European Contracts Convention: The Rome Convention on the Choice of Law for Contracts. 2nd ed. London, 2001;

14. Sornarajah M. The International Law on Foreign Investment. Cambridge, 1994;

15. Vernooij N.W. Rome I. An update on the law applicable to contractual obligations in Europe // The Columbia Journal of European Law Online 